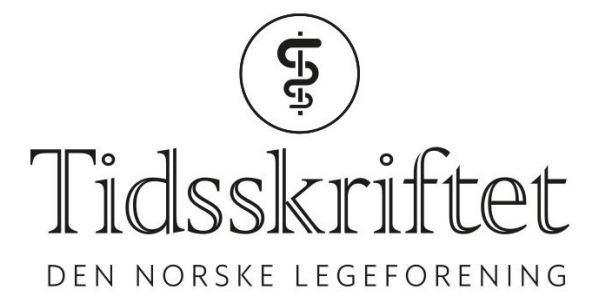

\title{
Rettelse: Ryggmargsstimulering mot perifere nevropatiske smerter
}

RETTELSE

BÅRD LUNDELAND

MAREN TOENNIS

MARK ZÜCHNER

LARS JANERÅS

AUDUN STUBHAUG

PER HANSSON

Tidsskr Nor Legeforen 2021; 141: 858-61.

I Tidsskriftet nr. 9/2021, s. 86o skal Figur 1 se slik ut (merk liten endring i stiplet linje):
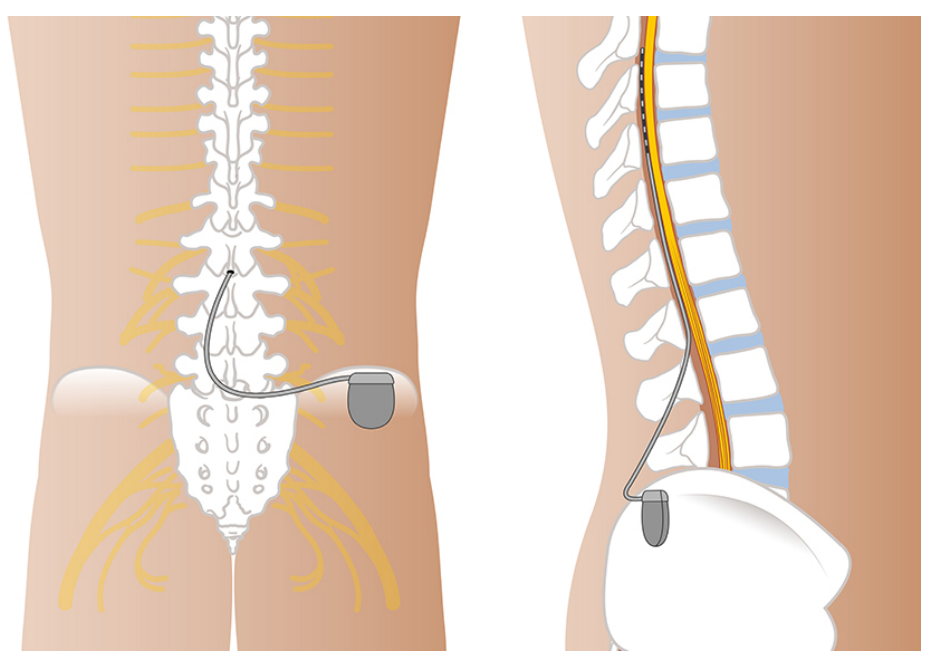

Figur 1 Ryggmargsstimuleringssystem med epidural elektrode og subkutan pulsgenerator. Illustrasjon: Øystein Horgmo, Universitetet i Oslo

Vi beklager feilen, den er rettet på nett. 
Publisert: 10. juni 2021. Tidsskr Nor Legeforen. DOI: 10.4045/tidsskr.21.0453

(C) Tidsskrift for Den norske legeforening 2020. Lastet ned fra tidsskriftet.no 